\title{
Month of birth, vitamin D and risk of immune- mediated disease: a case control study
}

\author{
Giulio Disanto ${ }^{1,2 \dagger}$, George Chaplin ${ }^{3 \dagger}$, Julia M Morahan ${ }^{1,2}$, Gavin Giovannoni ${ }^{4}$, Elina Hyppönen ${ }^{5}$, George C Ebers ${ }^{1,2^{*}}$ \\ and Sreeram $\vee$ Ramagopalan $1,2,4,6^{*}$
}

\begin{abstract}
Background: A season of birth effect in immune-mediated diseases (ID) such as multiple sclerosis and type 1 diabetes has been consistently reported. We aimed to investigate whether season of birth influences the risk of rheumatoid arthritis, Crohn's disease, ulcerative colitis and systemic lupus erythematosus in addition to multiple sclerosis, and to explore the correlation between the risk of ID and predicted ultraviolet B (UVB) light exposure and vitamin D status during gestation.

Methods: The monthly distribution of births of patients with ID from the UK ( $n=115,172)$ was compared to that of the general population using the Cosinor test. Predicted UVB radiation and vitamin D status in different time windows during pregnancy were calculated for each month of birth and correlated with risk of ID using the Spearman's correlation coefficient.

Results: The distributions of ID births significantly differed from that of the general population $\left(P=5 e^{-12}\right)$ with a peak in April (odds ratio $=1.045,95 \%$ confidence interval $=1.024,1.067, P<0.0001$ ) and a trough in October (odds ratio $=0.945,95 \%$ confidence interval $=0.925,0.966, P<0.0001$ ). Stratification by disease subtype showed seasonality in all ID but Crohn's disease. The risk of ID was inversely correlated with predicted second trimester UVB exposure (Spearman's rho $=-0.49, P=0.00005$ ) and third trimester vitamin D status (Spearman's rho $=-0.44$, $P=0.0003)$.

Conclusions: The risk of different ID in the UK is significantly influenced by the season of birth, suggesting the presence of a shared seasonal risk factor or factors predisposing to ID. Gestational UVB and vitamin D exposure may be implicated in the aetiology of ID.
\end{abstract}

\section{Background}

Complex disorders such as immune-mediated diseases (ID) are defined as conditions that have no single cause but result from a combination of genetic and environmental factors and their interactions. ID affect approximately $5 \%$ to $10 \%$ of the developed world and the overall incidence seems to be increasing [1]. This observation suggests that changes in environment and lifestyle play a central role in influencing prevalence.

Seasonality dominates the global environment and diet is closely related to seasonality by the effect of these environmental fluctuations on agriculture [2]. Seasonal

\footnotetext{
*Correspondence: george.ebers@cIneuro.ox.ac.uk; s.ramagopalan@qmul.ac.uk

+ Contributed equally

'Wellcome Trust Centre for Human Genetics, University of Oxford, Oxford, UK OX3 7BN

Full list of author information is available at the end of the article
}

factors can potentially act even before birth, when, according to the 'fetal origin of adult disease hypothesis', environmental influences leading to changes in embryonic or fetal tissue structure and function can influence the risk of adult physiological and pathological conditions $[3,4]$. As a consequence, being born at a certain time of the year may influence susceptibility to disease later in life. Indeed, month of birth effects have already been documented in ID such as multiple sclerosis (MS) and type 1 diabetes (T1D) [5-7]. In addition to MS and T1D, a few other studies have investigated the presence of a month of birth effect in other ID. However, poor sample sizes and inadequate statistical methods have significantly hampered these attempts and results are inconsistent [8-16].

The mechanisms involved in the pathogenesis of ID are variable, and both adaptive and innate immune

\section{Biomed Central}


responses have been implicated in diseases such as MS, rheumatoid arthritis (RA), systemic lupus erythematosus (SLE), Crohn's disease (CD) and ulcerative colitis (UC) [17-20]. For example, in MS and RA tolerance breakdown is thought to cause immune-mediated demyelination of the central nervous system and cartilage and bone destruction respectively $[18,21]$. By contrast, several lines of evidence suggest that $C D$ and $U C$ arise from an inappropriate immune reaction to the intestinal microbiota in genetically predisposed hosts [20]. Despite these differences, an abnormal activation of the immune system is a common thread linking these conditions and several observations indicate that similar genetic pathways and environmental agents, such as vitamin D deficiency, smoking behaviour and various infections, are involved in the pathogenesis of these disorders [18-20,22-25].

This led us to the a priori hypothesis that a similar seasonality of birth may be present among different ID. We investigated whether the month of birth influences susceptibility to RA, SLE, CD and UC in addition to MS using the largest cohort to date to investigate these effects $(n=115,172)$. Since all these conditions have been linked to vitamin D deficiency [23,24], we also tested whether the risk of disease by month of birth follows the same seasonal distribution of predicted ultraviolet $\mathrm{B}$ (UVB) light radiation and 25-hydroxyvitamin D (25-OH-D) levels during gestation.

\section{Methods}

Month of birth for MS ( $\mathrm{n}=15,492)$, RA ( $\mathrm{n}=39,666)$, SLE $(n=4,046), \operatorname{CD}(\mathrm{n}=20,574)$ and UC $(\mathrm{n}=23,892)$ patients seen by a doctor between 1997 and 2009 in Scotland and between 2003 and 2009 in England were obtained from the National Health Service (NHS) Scotland and the English Hospital Episode Statistics (HES). For MS, an additional cohort of patients $(n=11,502)$ and matched controls was collected as previously described [5], giving a total of 26,994 MS patients. General population controls were obtained from the General Register Office http://www.gro-scotland.gov.uk/ and the Office for National Statistics http://www.ons.gov.uk/. Scottish controls were based on month of birth registration between 1954 and 1973 and actual month of birth between 1974 and 1990. English controls were based on actual month of birth between 1950 and 1990. In total, month of birth data were collected for 115,172 patients with ID (26,162 English and 89,010 Scottish, Table 1) as well as for 3,028,621 Scottish and 29,202,890 English controls.

We compared cases and controls using the Cosinor test, which is able to capture seasonal distributions and is particularly suitable for relatively simple and symmetric seasonal patterns. This test fits a generalized linear model under the Poisson distribution using sine and cosine terms that together describe the sinusoid. In addition to statistical significance, the model provides information on the amplitude (the height) and the phase (the peak point from 1 to 12 indicating months) of the predicted sinusoid [26]. Monthly odds ratios (OR) were also calculated by comparing frequencies of patients and controls born in a certain month versus the rest of the year.

Average monthly UVB radiation at the wavelength of $305 \mathrm{~nm}$ at noon (joules/square metre) in England and Scotland between 1979 and 1992 was obtained from the National Aeronautics and Space Administration's Total Ozone Mapping Program on the Nimbus 7 satellite, as previously described [27]. Average monthly 25-OH-D levels were collected from a large cohort of adult Scottish and English women $(n=3,787)$ as previously described [28] and used as a proxy for the seasonal variation in gestational vitamin D status. Average predicted UVB exposure as well as vitamin D status during the first, second and third trimesters of gestation were calculated for each month of birth and tested for correlation with risk of ID (monthly OR) using the Spearman's correlation coefficient. Statistical analyses were performed using $\mathrm{R}$.

\section{Results}

To assess whether month of birth influences susceptibility to immune disorders, we initially compared the distribution of all patients with ID with that of the general population. Using the Cosinor test, the birth distribution of patients with ID was found to follow a seasonal distribution as compared with the general population $\left(P=5 \mathrm{e}^{-12}\right.$, amplitude $=0.033$, phase $=3.08$, low point $=9.08)$. When monthly ORs were calculated, a statistically significant peak was found in April $(\mathrm{OR}=1.045,95 \% \mathrm{CI}=1.024$ to $1.067, P<0.0001)$ and a significant trough exactly six months later in October $(\mathrm{OR}=0.945,95 \% \mathrm{CI}=0.925$ to $0.966, P<0.0001)$. A smaller deficit was also detected in August $(\mathrm{OR}=0.972,95 \% \mathrm{CI}=0.951$ to $0.9927, P=0.008)$

Table 1 Total number of patients with immune-mediated diseases used in the analysis

\begin{tabular}{llllll}
\hline & $\begin{array}{l}\text { Multiple } \\
\text { sclerosis }\end{array}$ & $\begin{array}{l}\text { Rheumatoid } \\
\text { arthritis }\end{array}$ & $\begin{array}{l}\text { Systemic lupus } \\
\text { erythematosus }\end{array}$ & $\begin{array}{l}\text { Crohn's } \\
\text { disease }\end{array}$ & $\begin{array}{l}\text { Ulcerative } \\
\text { colitis }\end{array}$ \\
\hline England & 13,075 & 4,747 & 1,622 & 2,463 & 4,255 \\
diseases \\
Scotland & 13,919 & 34,919 & 2,424 & 18,111 & 26,162 \\
Total & 26,994 & 39,666 & 4,046 & 20,574 & 23,892 \\
\hline
\end{tabular}


(Figure 1). The peak to trough ratio indicated the presence of a $6.5 \%$ increased risk for individuals born in April versus those born in October $(\mathrm{OR}=1.065,95 \% \mathrm{CI}=1.035$ to 1.096, $P<0.0001)$.

When the analysis was performed according to country, the seasonal effect appeared to be present in both England and Scotland (Scotland $P=5 \mathrm{e}^{-10}$, amplitude $=$ 0.034 , phase $=3.05$, low point $=9.05$; England $P=$ 0.005 , amplitude $=0.032$, phase $=3.23$, low point $=$ 9.23). The highest and lowest monthly ORs were found in the Scottish population; however, 95\%CIs were substantially overlapping (Figure 2).

The seasonality of birth detected by grouping all patients with ID could arise from a single disease such as MS, for which the presence of a month of birth effect has already been described. We therefore stratified the analysis by disease type. The Cosinor test indicated the presence of clear seasonality in all ID but CD: MS, $P=5 \mathrm{e}^{-06}$; amplitude $=0.041$, phase $=4.12$, low point $=10.12$; RA, $P=5 \mathrm{e}^{-04}$, amplitude $=0.032$, phase $=2.69$, low point $=$ 8.69; UC, $P=5 \mathrm{e}^{-04}$, amplitude $=0.04$, phase $=2.74$, low point $=8.74$; SLE, $P=0.025$, amplitude $=0.063$, phase $=$ 2.89 , low point $=8.89 ; \mathrm{CD}, P>0.05$. When calculating monthly ORs, a peak in spring and a deficit in autumn could be observed in each ID apart from CD, in which a January rather than spring peak was found. Birth percentages and monthly ORs with $95 \%$ CIs are presented in Table 2.

We next investigated whether the monthly risk of ID inversely correlated with predicted gestational UVB exposure and vitamin D status during different trimesters of pregnancy. Based on the Nimbus 7 satellite, $U V B$ radiation in the $U K$ reaches the minimum and maximum levels during winter (December to January) and summer (June to July), respectively. The highest and lowest 25-OH-D levels were collected during

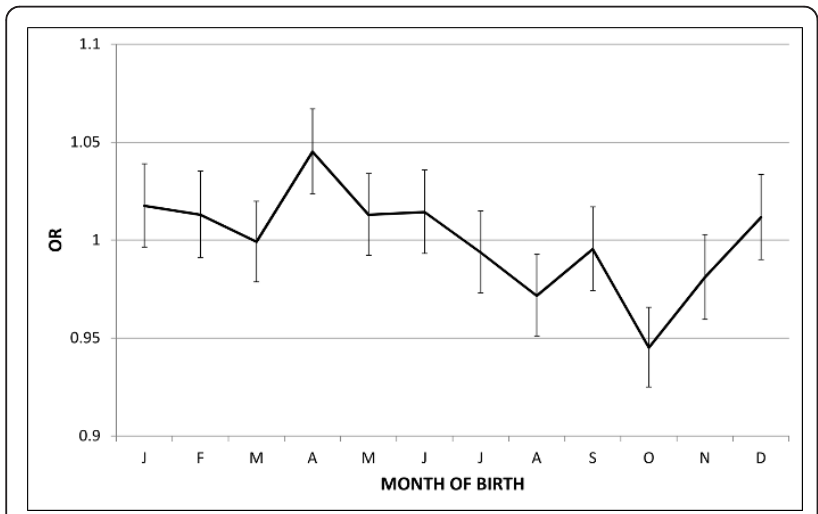

Figure 1 Odds ratio distribution with $95 \% \mathrm{Cl}$ based on month of birth in all immune-mediated diseases $(n=115,172)$ versus general population. April peak and October trough of risk can be observed.

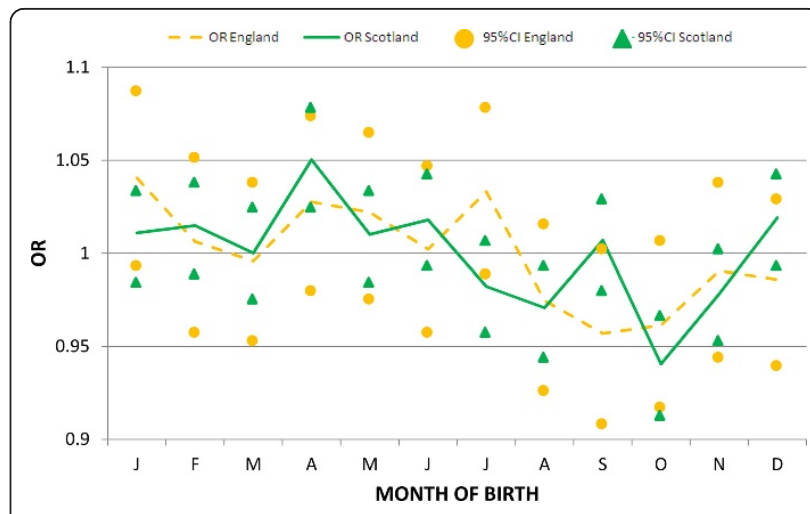

Figure 2 Odds ratio distribution based on month of birth in England and Scotland. The highest and lowest odds ratios are observed in Scotland but 95\%Cl substantially overlap.

September and February respectively [28]. Figure 3 shows the direct relation between UVB radiation and vitamin $\mathrm{D}$ status and the amount of time required for a change in UVB to impact on vitamin D metabolism. The peak and the trough of 25-OH-D levels are shifted approximately two to three months later than UVB radiation (two months lag: Spearman's rho $=0.91, P<$ $2.2 \mathrm{e}^{-16}$; three months lag: Spearman's rho $=0.88, P=$ 0.002). This is consistent with previous reports [29].

We found that the monthly risk of ID inversely correlated with predicted UVB exposure during the second trimester of pregnancy (Spearman's rho $=-0.49, P=$ $0.00005)$. Similarly, predicted maternal 25-OH-D levels were also inversely associated with risk of ID but the negative correlation was shifted to the third trimester (Spearman's rho $=-0.44, P=0.0003$ ) (Figure 4).

\section{Discussion}

We report here the largest study performed on ID and seasonality of birth. When patients with different conditions were grouped together, a clear seasonal birth distribution was observed with a peak in April and a trough exactly six months later in October. The effect size of being born at the 'wrong time' appears very low, with the highest ORs being under 1.1. However, considering the increased risk of all ID in the rest of the year versus October-born individuals and the proportion of the population born in months other than October, the population proportional attributable risk per cent is $5.05 \%$. This suggests that approximately $5 \%$ of ID cases could be prevented by ameliorating the risk factor responsible for the seasonal distribution of ID births. The season of birth effect was particularly clear in Scotland as compared with England, but no prominent differences between the two sites could be observed.

That the risk of MS varies by month of birth has already been shown in a number of regions, including 
Table 2 Birth percentages and monthly odds ratios with $95 \% \mathrm{Cl}$ for each and all immune-mediated diseases

\begin{tabular}{|c|c|c|c|c|c|c|c|c|c|}
\hline \multirow[t]{2}{*}{ Month } & \multicolumn{3}{|c|}{ All immune-mediated diseases } & \multicolumn{3}{|c|}{ Multiple sclerosis } & \multicolumn{3}{|c|}{ Rheumatoid arthritis } \\
\hline & Birth \% & OR & $95 \% \mathrm{Cl}$ & Birth \% & OR & $95 \% \mathrm{Cl}$ & Birth \% & OR & $95 \% \mathrm{Cl}$ \\
\hline Jan & 8.63 & $1.02+$ & 0.99 to 1.04 & 8.51 & 1.01 & 0.97 to 1.05 & 8.44 & 0.99 & 0.95 to 1.03 \\
\hline Feb & 7.90 & 1.01 & 0.99 to 1.04 & 7.76 & 0.99 & 0.95 to 1.03 & 7.94 & 1.02 & 0.98 to 1.06 \\
\hline Mar & 8.88 & 1.00 & 0.98 to 1.02 & 8.67 & 0.97 & 0.93 to 1.01 & 8.99 & 1.01 & 0.98 to 1.05 \\
\hline Apr & 8.77 & $1.05+$ & 1.02 to 1.07 & 8.79 & $1.05+$ & 1.002 to 1.09 & 8.78 & $1.05+$ & 1.01 to 1.08 \\
\hline May & 8.83 & 1.01 & 0.99 to 1.03 & 9.41 & $1.08+$ & 1.04 to 1.13 & 8.64 & 0.99 & 0.95 to 1.03 \\
\hline Jun & 8.44 & 1.01 & 0.99 to 1.04 & 8.70 & 1.04 & 1.01 to 1.09 & 8.47 & 1.02 & 0.98 to 1.06 \\
\hline Jul & 8.49 & 0.99 & 0.97 to 1.01 & 8.51 & 0.99 & 0.95 to 1.04 & 8.37 & 0.98 & 0.94 to 1.01 \\
\hline Aug & 8.16 & $0.97-$ & 0.95 to 0.99 & 8.20 & 0.98 & 0.94 to 1.02 & 8.14 & $0.97-$ & 0.93 to 1.00 \\
\hline Sep & 8.12 & 1.00 & 0.97 to 1.02 & 7.94 & 0.96 & 0.92 to 1.01 & 8.10 & 1.00 & 0.96 to 1.03 \\
\hline Oct & 8.05 & $0.95-$ & 0.92 to 0.97 & 8.08 & $0.96-$ & 0.92 to 1.00 & 8.20 & $0.96-$ & 0.93 to 0.99 \\
\hline Nov & 7.61 & 0.98 & 0.96 to 1.00 & 7.43 & $0.96-$ & 0.91 to 1.00 & 7.65 & 0.99 & 0.95 to 1.02 \\
\hline Dec & 8.11 & 1.01 & 0.99 to 1.03 & 8.01 & 1.00 & 0.96 to 1.04 & 8.30 & $1.04+$ & 1.00 to 1.07 \\
\hline \multirow[t]{2}{*}{ Month } & \multicolumn{3}{|c|}{ Ulcerative colitis } & \multicolumn{3}{|c|}{ Systemic lupus erythematosus } & \multicolumn{3}{|c|}{ Crohn's disease } \\
\hline & Birth \% & OR & $95 \% \mathrm{Cl}$ & Birth \% & OR & $95 \% \mathrm{Cl}$ & Birth \% & OR & $95 \% \mathrm{Cl}$ \\
\hline Jan & 8.63 & 1.02 & 0.97 to 1.06 & 9.57 & $1.14+$ & 1.03 to 1.27 & 8.99 & $1.06+$ & 1.01 to 1.11 \\
\hline Feb & 8.07 & $1.04+$ & 0.99 to 1.09 & 7.86 & 1.00 & 0.90 to 1.13 & 7.84 & 1.01 & 0.96 to 1.06 \\
\hline Mar & 8.90 & 1.00 & 0.96 to 1.05 & 8.75 & 0.98 & 0.88 to 1.09 & 8.94 & 1.01 & 0.96 to 1.06 \\
\hline Apr & 8.92 & $1.06+$ & 1.02 to 1.11 & 8.85 & 1.05 & 0.95 to 1.18 & 8.54 & 1.02 & 0.97 to 1.07 \\
\hline May & 8.73 & 1.00 & 0.96 to 1.05 & 9.71 & $1.12+$ & 1.01 to 1.24 & 8.40 & $0.96-$ & 0.91 to 1.01 \\
\hline Jun & 8.25 & 0.99 & 0.94 to 1.04 & 7.61 & 0.90 & 0.81 to 1.02 & 8.44 & 1.02 & 0.97 to 1.07 \\
\hline Jul & 8.44 & 0.99 & 0.94 to 1.03 & 8.58 & 1.00 & 0.90 to 1.12 & 8.75 & 1.03 & 0.98 to 1.08 \\
\hline Aug & 8.15 & $0.97-$ & 0.93 to 1.02 & 8.40 & 1.00 & 0.90 to 1.12 & 8.13 & 0.97 & 0.92 to 1.02 \\
\hline Sep & 8.18 & 1.00 & 0.96 to 1.05 & 7.51 & $0.91-$ & 0.81 to 1.02 & 8.45 & $1.04+$ & 0.99 to 1.10 \\
\hline Oct & 7.91 & $0.93-$ & 0.88 to 0.97 & 7.93 & 0.94 & 0.84 to 1.05 & 7.89 & $0.92-$ & 0.87 to 0.97 \\
\hline Nov & 7.69 & 0.99 & 0.95 to 1.04 & 7.09 & $0.91-$ & 0.81 to 1.03 & 7.78 & 1.00 & 0.95 to 1.06 \\
\hline Dec & 8.13 & 1.01 & 0.97 to 1.06 & 8.13 & 1.02 & 0.91 to 1.14 & 7.84 & 0.97 & 0.93 to 1.03 \\
\hline
\end{tabular}

+ and - indicate highest and lowest odds ratios, respectively. Cl: confidence intervals; OR: odds ratio.

Canada, Denmark, Sweden, Sardinia, Finland, England, Scotland and Australia [5,30-34]. We further confirmed these findings by increasing the sample size of a previously analysed cohort of UK patients with MS [5]. Based on the Cosinor test, RA, UC and SLE births also

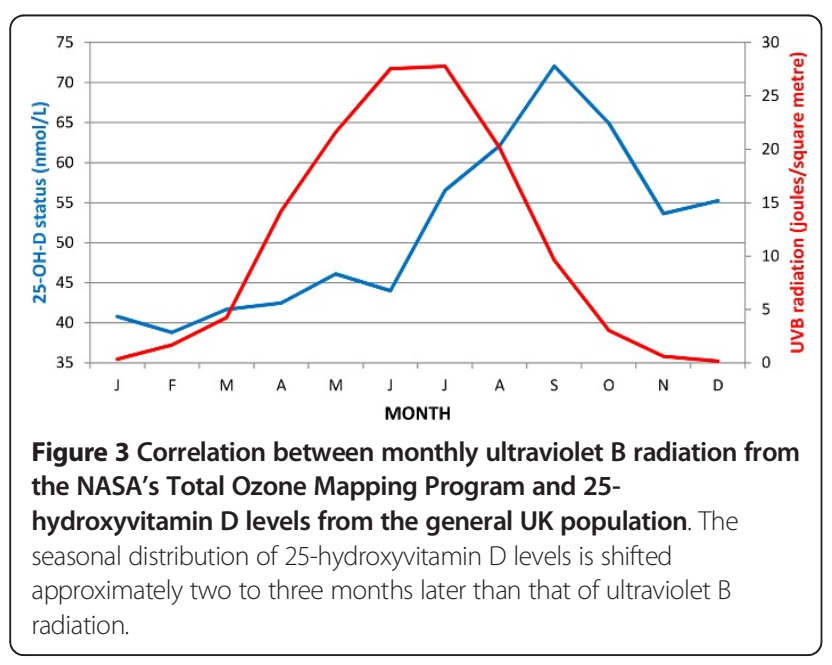

followed a clear seasonal distribution. Notably, all the predicted sinusoids peaked around the same period, with phases ranging from 2.69 to 4.12 (late winterspring). In contrast to other ID, the distribution of CD births was not seasonal.

The presence of seasonality of births among patients with UC but not CD is interesting but difficult to interpret. Somehow similar is the observation that the season of birth effect in MS is present among patients with relapsing remitting but not primary progressive MS [35]. It is therefore plausible to observe such differences between similar but distinct phenotypes. Furthermore, increasing evidence supports the presence of gene-environment interactions in disease aetiology $[36,37]$ and particular genetic variants could be involved and mediating the season of birth effect. Although many genetic variants influence the risk of both $\mathrm{UC}$ and $\mathrm{CD}$, many others (including variants located within the major histocompatibility complex) appear to be disease specific and this could contribute to the observed difference between UC and CD births [20,38-41].

A recent Australian study reported an inverse association between the risk of MS and UVB exposure during 


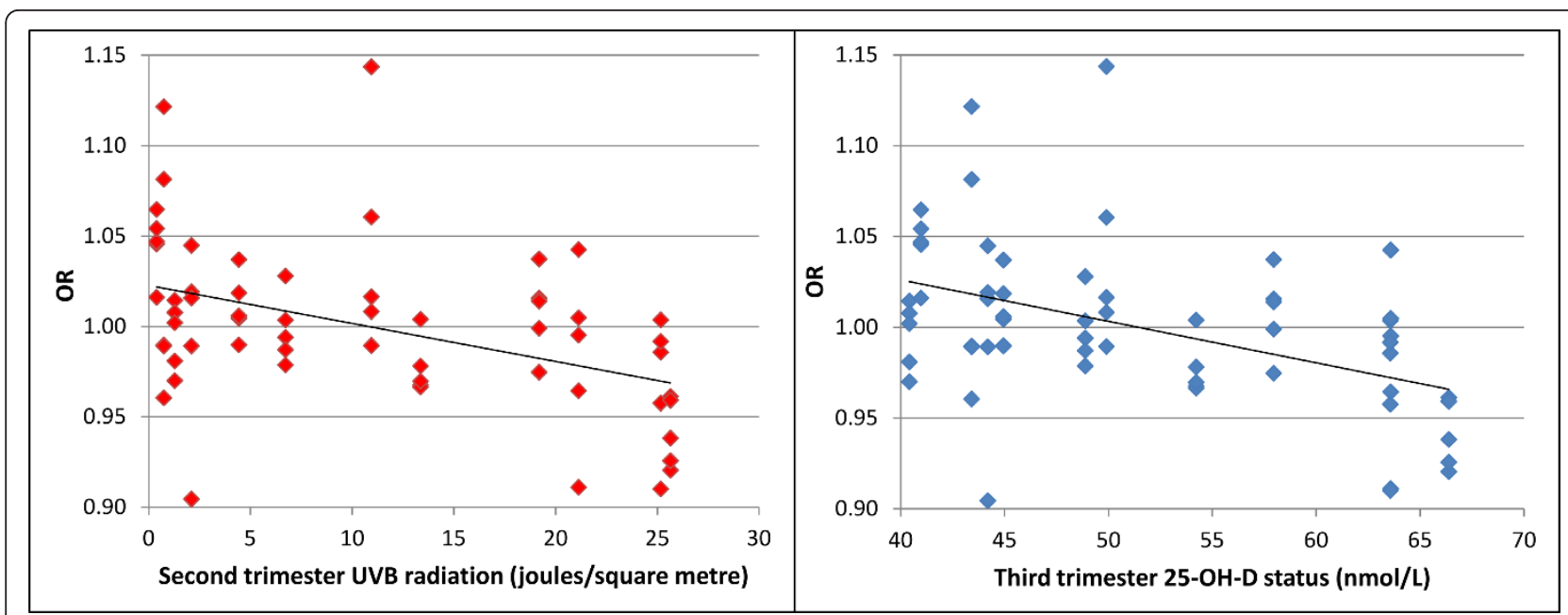

Figure 4 Inverse correlation between risk of immune-mediated diseases and predicted second trimester ultraviolet B exposure (left panel) and third trimester vitamin D status (right panel).

the first trimester of gestation [31]. However, the sample size was relatively small $(\mathrm{n}=1,524)$ and thus analysis had to be performed using bi-monthly periods. Furthermore, the seasonal variation of 25-OH-D levels was not investigated and no other studies have tried to answer the same question in ID other than MS. We found that the risk of ID was inversely associated with predicted second trimester UVB exposure and third trimester vitamin D status. These findings are interesting since several lines of evidence now support a role for vitamin $D$ deficiency in the pathogenesis of ID [23,24]. Notably, vitamin D production is strictly dependent on UVB radiation and vitamin $\mathrm{D}$ levels therefore follow a seasonal distribution [23]. This is also the case among pregnant women, whose vitamin D status largely depends on season and follows the same distribution as the levels of the general population $[28,42,43]$. Furthermore, in utero vitamin $\mathrm{D}$ deficiency has a significant effect on the developing immune system and our group has recently shown that genes associated with MS, RA, CD, SLE and T1D are significantly enriched for vitamin D receptor binding sites [44-46]. In addition to its well-known immunological roles, this exceptionally pleiotropic hormone has been implicated in autophagy and mucosal barrier homeostasis, which are thought to play a pathogenic role in CD and $\mathrm{UC}[20,47,48]$. It may be that in utero vitamin D deficiency, in conjunction with individual genetic variation and subsequent exposure to other environmental agents, may then lead to disease specificity. Notably, schizophrenia is also influenced by the season of birth and a recent study has shown that neonatal vitamin D levels are significantly associated with risk of schizophrenia later in life [49,50]. Future studies should try to answer the same question in MS as well as in other ID.
This study has limitations. Information on sex and ethnicity was not available and this may have confounded our results. Furthermore, the data we gathered from the Scottish NHS and the English HES could not be restricted to UK born but only to UK resident individuals. However, the enormous sample size (115,172 ID cases), the relatively homogeneous Scottish population and the strong a priori evidence for a month of birth effect in MS make the risk of a spurious association improbable. Furthermore, it is striking that the ID analysed (apart from CD) show a similar seasonal risk distribution, which is also the one reported in patients with T1D [6,7]. This makes the data unlikely to be a chance finding.

We were limited to using average UVB radiation and general population vitamin $\mathrm{D}$ measures, which may differ from the individual maternal exposures. It is important to note that our UVB and vitamin D correlation analysis does not prove causation and that, although the vitamin D hypothesis is supported by both epidemiological and functional observations, seasonality dominates many features of the global environment and other seasonal factors may play a role in determining the risk of ID. Climate, temperature, infectious disease and maternal nutrition are all characterised by seasonality and thus represent excellent candidate factors.

\section{Conclusions}

The susceptibility to different ID in the UK is influenced by the season of birth. This is particularly clear in patients with MS, RA, UC and SLE and suggests that at least some proportion of ID risk is preventable. Gestational vitamin D deficiency appears to be a plausible causative agent. The identification of the seasonal factor or factors responsible for such observations will be crucial for disease prevention strategies. 


\section{Abbreviations}

CD: Crohn's disease; HES: Hospital Episode Statistics; ID: immune-mediated disease; MS: multiple sclerosis; NHS: National Health Service; OR: odds ratio; RA: rheumatoid arthritis; SLE: systemic lupus erythematosus; T1D: type 1 diabetes; UC: ulcerative colitis; UVB: ultraviolet B; 25-OH-D: 25-hydroxyvitamin D.

\section{Acknowledgements}

This work was funded by a research fellowship FISM-Fondazione Italiana Sclerosi Multipla-Cod.: 2010/B/5; the Medical Research Council (GRANT NUMBER G0801976) and the Wellcome Trust (090532/Z/09/Z). The study sponsors had no role in the design and conduct of the study; collection, management, analysis, and interpretation of the data; and preparation, review, or approval of the manuscript. All authors state that this research was carried out independently of the influence of funding bodies.

\section{Author details}

${ }^{1}$ Wellcome Trust Centre for Human Genetics, University of Oxford, Oxford, UK OX3 7BN. ${ }^{2}$ Department of Clinical Neurology, University of Oxford, Oxford, UK OX3 9DU. ${ }^{3}$ Department of Anthropology, The Pennsylvania State University, Pennsylvania, United States of America, 16802. ${ }^{4}$ Blizard Institute of Cell and Molecular Science, Queen Mary University of London, Barts and The London School of Medicine and Dentistry, London, UK, E1 2AT. ${ }^{5}$ Centre for Paediatric Epidemiology and Biostatistics and MRC Centre of Epidemiology for Child Health, UCL Institute of Child Health, London, UK, WC1N 1EH. ${ }^{6}$ London School of Hygiene and Tropical Medicine, London, UK, WC1E 7HT.

\section{Authors' contributions}

GD was involved in the study concept and design, acquisition of data, analysis and interpretation of data, and drafting of the manuscript. GC was involved in the acquisition of data, analysis and interpretation of data and drafting of the manuscript. JMM critically revised the manuscript for important intellectual content. GG was involved in the acquisition of data and critical revision of the manuscript for important intellectual content. EH was involved in the acquisition of data and critical revision of the manuscript for important intellectual content. GCE was involved in the study concept and design, acquisition of data, critical revision of the manuscript for important intellectual content and study supervision. SVR was involved in the study concept and design, acquisition of data, analysis and interpretation of data, critical revision of the manuscript for important intellectual content and study supervision. All authors read and approved the final manuscript.

\section{Competing interests}

The authors declare that GD is funded by a research fellowship FISMFondazione Italiana Sclerosi Multipla-Cod.: 2010/B/5. JMM is funded by the MS Society of Australia and the UK. GG serves on scientific advisory boards for Merck Serono and Biogen Idec and Vertex Pharmaceuticals; served on the editorial board of Multiple Sclerosis; has received speaker honoraria from Bayer Schering Pharma, Merck Serono, Biogen Idec, Pfizer Inc., Teva Pharmaceutical Industries Ltd.-sanofiaventis, Vertex Pharmaceuticals, Genzyme Corporation, Ironwood, and Novartis; has served as a consultant for Bayer Schering Pharma, Biogen Idec, GlaxoSmithKline, Merck Serono, Protein Discovery Laboratories, Teva Pharmaceutical Industries Ltd.sanofiaventis, UCB, Vertex Pharmaceuticals, GW Pharma, Novartis, and FivePrime; serves on the speakers bureau for Merck Serono; and has received research support from Bayer Schering Pharma, Biogen Idec, Merck Serono, Novartis, UCB, Merz Pharmaceuticals, LLC, Teva Pharmaceutical Industries Ltd-sanofiaventis, GW Pharma, and Ironwood. EH holds a Department of Health (UK) Public Health Career Scientist Award. The Centre for Paediatric Epidemiology and Biostatistics, benefits from funding support from the MRC in its capacity as the MRC Centre of Epidemiology for Child Health. Research at the University College London Institute of Child Health and Great Ormond Street Hospital for Children NHS Trust benefits from R\&D funding received from the NHS Executive. GCE serves on the editorial boards of the International Multiple Sclerosis Journal and Multiple Sclerosis and as Section Editor for BMC Medical Genetics; has received funding for travel or speaker honoraria from Bayer Schering Pharma, sanofiaventis, Roche, and UCB; has served as a consultant to Biopartners, Bayer Schering Pharma, Howrey LLP, Heron Health, and Eli Lilly and Company; and receives research support from Bayer Schering Pharma, the Multiple Sclerosis Society of the
United Kingdom, and the Multiple Sclerosis Society of Canada Scientific Research Foundation. SVR receives research support from the Multiple Sclerosis Society of Canada Scientific Research Foundation and the Multiple Sclerosis Society of the United Kingdom. GC reports no competing interests. All authors have no relationships with companies that might have an interest in the submitted work in the previous three years; their spouses, partners, or children have no financial relationships that may be relevant to the submitted work; and have no non-financial interests that may be relevant to the submitted work.

Received: 24 April 2012 Accepted: 6 July 2012 Published: 6 July 2012

\section{References}

1. Shapira Y, Agmon-Levin N, Shoenfeld Y: Defining and analyzing geoepidemiology and human autoimmunity. J Autoimmun 2010, 34 J168-177.

2. In Seasonality Encyclopedia of Human Nutrition.. 2 edition. Edited by: Branca F, D'Acapito P. Oxford: Elsevier; 2005:

3. Barker DJ: The Wellcome Foundation Lecture, 1994. The fetal origins of adult disease. Proc Biol Sci 1995, 262:37-43.

4. Langley-Evans SC, McMullen S: Developmental origins of adult disease. Med Princ Pract 2010, 19:87-98.

5. Willer CJ, Dyment DA, Sadovnick AD, Rothwell PM, Murray TJ, Ebers GC: Timing of birth and risk of multiple sclerosis: population based study. BMJ 2005, 330:120

6. Kahn HS, Morgan TM, Case LD, Dabelea D, Mayer-Davis EJ, Lawrence JM Marcovina SM, Imperatore G: Association of type 1 diabetes with month of birth among U.S. youth: The SEARCH for Diabetes in Youth Study. Diabetes Care 2009, 32:2010-2015.

7. Rothwell P, Staines A, Smail P, Wadsworth E, McKinney P: Seasonality of birth of patients with childhood diabetes in Britain. BMJ 1996, 312(7044):1456-1457.

8. Ekbom A, Zack M, Adami HO, Helmick C: Is there clustering of inflammatory bowel disease at birth? Am J Epidemiol 1991, 134:876-886.

9. Haslam N, Mayberry JF, Hawthorne AB, Newcombe RG, Holmes GK, Probert CS: Measles, month of birth, and Crohn's disease. Gut 2000, 47:801-803.

10. Sorensen HT, Pedersen L, Norgard B, Fonager K, Rothman KJ: Does month of birth affect risk of Crohn's disease in childhood and adolescence? BMJ 2001, 323:907.

11. Chowers Y, Odes S, Bujanover Y, Eliakim R, Bar Meir S, Avidan B: The month of birth is linked to the risk of Crohn's disease in the Israeli population. Am J Gastroenterol 2004, 99:1974-1976.

12. Buchanan WW, Gregoire LG, Buchanan HM: Month of birth and rheumatoid arthritis. Lancet 1987, 2:517.

13. Sonnenberg A: Date of birth in the occurrence of inflammatory bowel disease. Inflamm Bowel Dis 2009, 15:206-211.

14. Card TR, Sawczenko A, Sandhu BK, Logan RF: No seasonality in month of birth of inflammatory bowel disease cases: a prospective population based study of British under 20 year olds. Gut 2002, 51:814-815.

15. Bai A, Guo Y, Shen Y, Xie Y, Zhu X, Lu N: Seasonality in flares and months of births of patients with ulcerative colitis in a Chinese population. Dig Dis Sci 2009, 54:1094-1098.

16. Angelucci E, Cocco A, Cesarini M, Crudeli A, Necozione S, Caprilli R, Latella G: Monthly and seasonal birth patterns and the occurrence of Crohn's disease. Am J Gastroenterol 2009, 104:1608-1609.

17. Kasper LH, Shoemaker J: Multiple sclerosis immunology: the healthy immune system vs the MS immune system. Neurology 2010, 74(Suppl 1): S2-8.

18. Mclnnes IB, Schett G: The pathogenesis of rheumatoid arthritis. N Engl J Med 2011, 365:2205-2219.

19. Tsokos GC: Systemic lupus erythematosus. N Engl J Med 2011, 365:2110-2121.

20. Kaser A, Zeissig S, Blumberg RS: Inflammatory bowel disease. Annu Rev Immunol 2010, 28:573-621.

21. Noseworthy $J \mathrm{H}$, Lucchinetti $\mathrm{C}$, Rodriguez M, Weinshenker BG: Multiple sclerosis. N Engl J Med 2000, 343:938-952.

22. Baranzini SE: The genetics of autoimmune diseases: a networked perspective. Curr Opin Immunol 2009, 21:596-605.

23. Holick MF: Vitamin D deficiency. N Engl J Med 2007, 357:266-281. 
24. Shoenfeld $\mathrm{N}$, Amital $H$, Shoenfeld $Y$ : The effect of melanism and vitamin D synthesis on the incidence of autoimmune disease. Nat Clin Pract Rheumatol 2009, 5:99-105.

25. Ramagopalan SV, Dobson R, Meier UC, Giovannoni G: Multiple sclerosis: risk factors, prodromes, and potential causal pathways. Lancet Neurol 2010, 9:727-739.

26. In Analysing Seasonal Health Data. Edited by: Barnett AG, Dobson AJ. Dordrecht Springer; 2010:.

27. Ramagopalan SV, Handel AE, Giovannoni G, Rutherford Siegel S, Ebers GC, Chaplin G: Relationship of UV exposure to prevalence of multiple sclerosis in England. Neurology 2011, 76:1410-1414.

28. Hypponen E, Power C: Hypovitaminosis D in British adults at age $45 \mathrm{y}$ : nationwide cohort study of dietary and lifestyle predictors. Am J Clin Nutr 2007, 85:860-868.

29. Parfitt AM, Gallagher JC, Heaney RP, Johnston CC, Neer R, Whedon GD: Vitamin D and bone health in the elderly. Am J Clin Nutr 1982, 36:1014-1031.

30. Sotgiu S, Pugliatti M, Sotgiu MA, Fois ML, Arru G, Sanna A, Rosati G: Seasonal fluctuation of multiple sclerosis births in Sardinia. J Neurol 2006, 253:38-44.

31. Staples J, Ponsonby A, Lim L: Low maternal exposure to ultraviolet radiation in pregnancy, month of birth, and risk of multiple sclerosis in offspring: longitudinal analysis. BMJ 2010, 340:C1640.

32. Templer DI, Trent NH, Spencer DA, Trent A, Corgiat MD, Mortensen PB, Gorton M: Season of birth in multiple sclerosis. Acta Neurol Scand 1992, 85:107-109.

33. Wiberg M, Templer D: Season of birth in multiple sclerosis in Sweden: Replication of Denmark findings. J Orthomol Med 1994, 9:71-74.

34. Saastamoinen KP, Auvinen MK, Tienari PJ: Month of birth is associated with multiple sclerosis but not with HLA-DR15 in Finland. Mult Scler 2012, 18(5):563-568.

35. Sadovnick AD, Duquette P, Herrera B, Yee IM, Ebers GC: A timing-of-birth effect on multiple sclerosis clinical phenotype. Neurology 2007, 69:60-62.

36. Dempfle A, Scherag A, Hein R, Beckmann L, Chang-Claude J, Schafer H: Gene-environment interactions for complex traits: definitions, methodological requirements and challenges. Eur J Hum Genet 2008, 16:1164-1172.

37. Feil R, Fraga MF: Epigenetics and the environment: emerging patterns and implications. Nat Rev Genet 2011, 13:97-109.

38. Franke A, McGovern DP, Barrett JC, Wang K, Radford-Smith GL, Ahmad T, Lees CW, Balschun T, Lee J, Roberts R, Anderson CA, Bis JC, Bumpstead S, Ellinghaus D, Festen EM, Georges M, Green T, Haritunians T, Jostins L, Latiano A, Mathew CG, Montgomery GW, Prescott NJ, Raychaudhuri S, Rotter Jl, Schumm P, Sharma Y, Simms LA, Taylor KD, Whiteman D, et al: Genome-wide meta-analysis increases to 71 the number of confirmed Crohn's disease susceptibility loci. Nat Genet 2010, 42:1118-1125.

39. Anderson CA, Boucher G, Lees CW, Franke A, D'Amato M, Taylor KD, Lee JC, Goyette P, Imielinski M, Latiano A, Lagacé C, Scott R, Amininejad L, Bumpstead S, Baidoo L, Baldassano RN, Barclay M, Bayless TM, Brand S, Büning C, Colombel JF, Denson LA, De Vos M, Dubinsky M, Edwards C, Ellinghaus D, Fehrmann RS, Floyd JA, Florin T, Franchimont D, et al: Metaanalysis identifies 29 additional ulcerative colitis risk loci, increasing the number of confirmed associations to 47. Nat Genet 2011, 43:246-252.

40. Waterman M, Xu W, Stempak JM, Milgrom R, Bernstein CN, Griffiths AM, Greenberg GR, Steinhart AH, Silverberg MS: Distinct and overlapping genetic loci in Crohn's disease and ulcerative colitis: correlations with pathogenesis. Inflamm Bowel Dis 2011, 17:1936-1942.

41. Okada Y, Yamazaki K, Umeno J, Takahashi A, Kumasaka N, Ashikawa K, Aoi T, Takazoe M, Matsui T, Hirano A, Matsumoto T, Kamatani N, Nakamura Y, Yamamoto K, Kubo M: HLA-CW*1202-B*5201-DRB1*1502 haplotype increases risk for ulcerative colitis but reduces risk for Crohn's disease. Gastroenterology 2011, 141:864-871 e861-865.

42. Kimball S, Fuleihan Gel H, Vieth R: Vitamin D: a growing perspective. Crit Rev Clin Lab Sci 2008, 45:339-414.

43. Holmes VA, Barnes MS, Alexander HD, McFaul P, Wallace JM: Vitamin D deficiency and insufficiency in pregnant women: a longitudinal study. $\mathrm{Br}$ J Nutr 2009, 102:876-881.

44. Harvey L, Burne TH, McGrath JJ, Eyles DW: Developmental vitamin D3 deficiency induces alterations in immune organ morphology and function in adult offspring. J Steroid Biochem Mol Biol 2010, 121:239-242.
45. Yu S, Cantorna MT: Epigenetic reduction in rnvariant NKT cells following in utero vitamin D veficiency in mice. J Immunol 2011, 186:1384-1390.

46. Ramagopalan SV, Heger A, Berlanga AJ, Maugeri NJ, Lincoln MR, Burrell A, Handunnetthi L, Handel AE, Disanto G, Orton SM, Watson CT, Morahan JM, Giovannoni G, Ponting CP, Ebers GC, Knight JC: A ChIP-seq defined genome-wide map of vitamin $D$ receptor binding: associations with disease and evolution. Genome Res 2010, 20:1352-1360.

47. Wu S, Sun J: Vitamin D, vitamin D receptor, and macroautophagy in inflammation and infection. Discov Med 2011, 11:325-335.

48. Kong J, Zhang Z, Musch MW, Ning G, Sun J, Hart J, Bissonnette M, Li YC: Novel role of the vitamin $D$ receptor in maintaining the integrity of the intestinal mucosal barrier. Am J Physiol Gastrointest Liver Physiol 2008, 294 G208-216.

49. Davies G, Welham J, Chant D, Torrey EF, McGrath J: A systematic review and meta-analysis of Northern Hemisphere season of birth studies in schizophrenia. Schizophr Bull 2003, 29:587-593.

50. MCGrath JJ, Eyles DW, Pedersen CB, Anderson C, Ko P, Burne TH, NorgaardPedersen B, Hougaard DM, Mortensen PB: Neonatal vitamin D status and risk of schizophrenia: a population-based case-control study. Arch Gen Psychiatry 2010, 67:889-894

\section{Pre-publication history}

The pre-publication history for this paper can be accessed here: http://www.biomedcentral.com/1741-7015/10/69/prepub

doi:10.1186/1741-7015-10-69

Cite this article as: Disanto et al:: Month of birth, vitamin D and risk of immune-mediated disease: a case control study. BMC Medicine 2012 10:69.

\section{Submit your next manuscript to BioMed Central and take full advantage of:}

- Convenient online submission

- Thorough peer review

- No space constraints or color figure charges

- Immediate publication on acceptance

- Inclusion in PubMed, CAS, Scopus and Google Scholar

- Research which is freely available for redistribution 